\title{
La dramaturgia anarquista en Chile. Un discurso de resistencia cultural ${ }^{*}$
}

\author{
The anarchistic dramaturgy in Chile. A discourse of cultural resistance
}

\author{
Sergio Pereira Poza \\ Universidad de Santiago de Chile, Facultad de Humanidades, Departamento de Lingüística \\ y Literatura, Avenida. Bernardo O'Higgins 3363, Santiago, Chile, \\ e-mail: sergiopereira@usach.cl
}

La dramaturgia anarquista chilena de comienzos del siglo XX es vista como una de las tantas formas de resistencia cultural que el movimiento libertario opone a un sistema cerrado, elitista y excluyente, buscando contrastar polémicamente el discurso positivo y complaciente de un orden que funda un modo único de comprensión y representación de la realidad combatiendo, ocultando o reprimiendo toda otra forma de visión alternativa. La estrategia seguida es la de disputar simbólicamente los espacios de significación administrados por el poder burgués, para lo cual replica los medios de producción y de circulación vigentes, aunque planteándose como un discurso independiente del poder y de cualquiera forma de hegemonía cultural.

Palabras clave: anarquismo, resistencia cultural, dramaturgia.

The anarchistic Chilean dramaturgy of the early 20th century is seen as one of the many forms of cultural resistance that the libertarian movement putted up against a closed, elitist and excluding system, intending to polemically contrast the positive and complaisant discourse of an order that established a single way of comprehension and representation of reality and which fought, concealed or suppressed all other alternative forms of vision. The strategy followed was that of symbolically disputing the spaces of significance administered by the bourgeois power, and in this connection the approach was to replicate the current means of production and media, although stating a discourse independent from the power and any form of cultural hegemony.

Key words: anarchism, cultural resistance, dramaturgy.

\section{INTRODUCCIÓN}

La irrupción de la escritura dramática anarquista en Chile al promediar el último tercio del siglo XIX presenta como correlato una realidad política, social y cultural que se debate entre la conservación del ejercicio autoritario y excluyente del poder

\footnotetext{
* Este trabajo es parte del resultado de la investigación Fondecyt N 1070128 (Conicyt) "La dramaturgia anarquista en Chile. Un discurso de Resistencia".
} 
oligárquico y la sustitución, alentada por quienes han vivido bajo la lógica de la dominación. El discurso dramático ácrata es parte de esos movimientos que luchan en la época por desbaratar el monoculturalismo en nombre de la diversidad. Para el anarquismo, en general, la tarea histórica que se autoasigna es la de recuperar el contenido moral que una vez otorgó legitimidad al proyecto de la Ilustración, y que el liberalismo transó por el puñado de monedas que tomó de las arcas del capitalismo industrial en pleno proceso de desarrollo en toda Europa. Más que imponer sus propios aparatos de legitimación, el anarquismo busca formar una conciencia crítica de la realidad en función de los olvidados principios de la equidad social, de la solidaridad, de la tolerancia cultural y de la libertad del hombre, dentro de un modelo de sociedad prefigurado por el discurso iluminista. Es en contra de las culturas de élites, herederas del legado capitalista burgués, que el anarquismo chileno desplegará sus auténticas banderas de lucha, disputándoles en su propio campo los espacios culturales construidos desde los albores de la República. Lo que en esta contienda simbólica está en juego es el control de los sistemas simbólicos, de las definiciones y los significados que dan sentido a la realidad. La orgánica libertaria crea una resistencia discursiva que se afirma fundamentalmente en la transgresión a lo normado, a lo ritualizado, por el orden plutocrático. Ante este objetivo, la acción emprendida por el movimiento consistirá en producir sus propios espacios culturales, capaces de diseñar una concepción alternativa del mundo. El objetivo de crear estos espacios culturales en oposición a los existentes se plantea como una confrontación que se da en el terreno de lo cultural más que en lo político coyuntural, no tanto porque el libertarismo renuncia a la conquista del poder político, sino porque el ámbito natural de sus actos se focalizará en la defensa de las creencias, los valores, la tradición, el género, las costumbres, el lenguaje. Resulta, entonces, decisivo alcanzar el control simbólico de los sistemas de creación y divulgación del modelo de sociedad a que aspira la idea libertaria.

La dramaturgia anarquista es parte de esta lógica de guerra simbólica, lo mismo que la hoja periodística, el relato histórico, el arte y el resto de los niveles de expresión. Representará el mundo desde la mirada de un territorio que se ha mantenido en la periferia por la acción excluyente del sistema imperante. El discurso dramático libertario contribuirá a reactivar la conciencia crítica de los excluidos, convirtiéndolos en impulsos colectivos que transformen la acción en acción revolucionaria. Y es, justamente, este carácter alternativo de su palabra ácrata el que conferirá a su escritura lo que en este trabajo se denominará de resistencia. Resistencia a los privilegios de minorías que defienden una cultura afirmativa que todo lo reduce a una interpretación homogénea de la realidad, en la que el sentido de la integración social y nacional neutraliza cualquier intento diversificador de pensamientos y visiones. Resistencia a los gestos y actitudes mesiánicos de una intelectualidad ilustrada que se erige en la única y exclusiva procesadora del saber y de la moral de la sociedad entera. Resistencia al cercenamiento y amordazamiento de la cultura popular, sinónimo de "barbarie" y, por lo mismo, ajena al cultivo de la alta cultura y de las bellas artes, de acuerdo con los patrones estéticos eurocentristas. La resistencia, en buenas cuentas, a esa vieja oligarquía de cuño hispánico que profitaba de un poder heredado de los antiguos encomenderos coloniales y de los primeros latifundistas y terratenientes de la República, y que en los albores del siglo XX, ya constituidos en clase, comienzan a enfrentarse entre ellos mismos por asignaciones de poder. 
En este trabajo nos proponemos revisar los avatares de la escritura dramática libertaria en el contexto de las grandes transformaciones que acompañan los años que preceden la llegada del siglo XX en Chile hasta su época de consolidación alrededor de la segunda década del siglo anterior. Nos interesa subrayar el carácter intelectual y moral que presenta el discurso anarquista, calidad que reafirma la voluntad del pensamiento ácrata de representar a través de su dramaturgia un orden nuevo que restablezca las condiciones igualitarias y fraternas de existencia, perdidas u olvidadas en medio del tráfago del capitalismo burgués. Queremos certificar que la producción dramática anarquista se plantea como uno de los mecanismos discursivos de resistencia encargados de desplazar los circuitos de creación y transmisión de la cultura elitista por otro que dé cabida a la diversidad.

\section{El ESPACIO CULTURAL ALTERNATIVO}

El proyecto anarquista se definió, desde su instalación en Chile, como la punta de lanza para sustituir lo existente. Había claridad en su estrategia de que ninguna demanda orgánica tendría éxito si previamente no se reemplazaban los mecanismos institucionales que intervenían directamente en la regulación de las instancias de producción, intermediación y valoración de los bienes simbólicos. Esta tarea de sustituir lo antiguo por lo nuevo correspondía a la acción revolucionaria misma que proclamaba su doctrina. Los avances que la oligarquía gobernante podía exhibir en lo social y económico tenían un solo derrotero, encaminado siempre a favorecer a los sectores pudientes y comprometidos con el plan nacional, si bien, a estas alturas, ya podía apreciarse una recatada apertura hacia los sectores ilustrados medios de la sociedad, más que con ánimo inclusivo culturalmente hablando con un propósito de ampliación de su tradicional zona de influencia. El discurso oficial no hablaba ni reconocía nada que no estuviera delimitado por el horizonte que estos grupos elitistas habían determinado. Multilateralizar la mirada significaba encontrarse con una realidad social cuyo discurso se había negado a enfrentar, por las condiciones de marginalidad que presentaba y porque contradecía los supuestos de unidad e integración proclamados por la cultura eliticéntrica. La fragilidad discursiva que el tradicionalismo había mostrado en sus intentos por justificar el orden que promovía, dejaba entrever intersticios que negaban la validez de los principios igualitarios propalados por el proyecto ilustrado original, en particular aquellos que consagraban la perpetua exclusión de lo popular y la expoliación sistemática de los grupos asalariados. El anarquismo perseguía, pues, un espacio propio desde el cual forzar a la cultura central a reconocer las restricciones en los procesos de construcción de los sistemas de representación del mundo, de la naturaleza y del orden social. El principal argumento esgrimido era el falso espectáculo que ofrecía una sociedad, que preparaba los ostentosos festejos del centenario del año 10, cuando a pocas cuadras del centro de la ciudad capital se apretujaba una población sumida en el hambre y el horror. Era impresentable para todo aquel que tuviera una pizca de sensatez contemplar que al lado de "la ciudad oligárquica, caracterizada por los 'beaux quartiers", preparándose para exhibir sus mejores galas, se erigieran espacios que contenían lo más expresivo de la pobreza y el abandono. Era el lado oscuro de la realidad, constituido por "los de abajo: hombres y mujeres de las penumbras, los sótanos, el encogimiento y la pestilencia /.../" (Viñas 2004:17). 
Las diferencias entre un mundo y otro se volvían más severas en la medida que el eliticentrismo extremaba su discurso afirmativo, persuadiendo al destinatario a compartir la complacencia de una nación que mantenía inalterables los lazos de unión entre todos sus ciudadanos. La lucha por los espacios culturales, según expresión de Bourdieu, se planteaba en Chile como una acción destinada a crear espacios, por una parte, destinados a producir y difundir las creencias legitimadoras de lo establecido y, por la otra, inspirados por la idea de la sustitución, incubada al calor de la cultura de resistencia. Para el anarquismo, la auténtica relación armónica entre los individuos partía de la comunidad de imágenes y representaciones, reafirmadoras del sentido de identidad colectiva que la cultura popular buscaba como respuesta al hegemonismo monocultural del poder estatuido. Luego, cualquier resultado de esta lucha dependía de las instancias mediadoras encargadas de transmitir el mensaje funcional a los intereses de cada bando. En este tramo de la contienda de supremacías ideológicas y culturales, el polo libertario debía desarrollar sus capacidades de resistencia ante la embestida institucional que caricaturizaba, a través de sus aparatos hegemónicos, en especial, la prensa afín, el descontento popular como fruto de la envidia y el resentimiento, inoculados por levantiscos que rendían pleitesía al agnosticismo y se movían al ritmo de las enseñas rojinegras. Quizás uno de los expedientes más socorridos de la autoridad era el descrédito oficial de la cultura popular, sindicándola como el contenido arcaico que, por naturaleza, pertenece al pasado y, por lo mismo, está asociado con lo premoderno y lo subsidiario (Cf. García Canclini 2005: 195).

Para el anarquismo, el camino seguido tenía que ser aquel que neutralizara la acción difusora de los medios institucionales de la sociedad capitalista, apropiándose del papel de la escuela, de la función de la prensa, de la influencia de la Iglesia y de los sistemas simbólicamente representacionales. Su respuesta estaba por el lado de implementar sus propios mecanismos de creación y divulgación, estableciendo una educación libre que se atuviera a los principios humanitaristas y científicos de la cultura alternativa, siguiendo los pasos de la nueva escuela europea; competir en el terreno del periodismo con un circuito propio que divulgara el pensamiento orgánico de los ácratas; poner de manifiesto la connivencia de la religión con los poderes oligárquicos para comunicar la redención, pátina que encubre un espíritu represivo; establecer un contradiscurso artístico y literario cuya propuesta de mundo se colocara más allá de la realidad fáctica, en el sitio donde es posible tocar el futuro por su lado de acá (Cf. Bhabha 2002). Nacía la pugna por disputar la tribuna desde la cual se pudieran legitimar o no los proyectos en curso. En ambos casos, se desarrollaba una cultura que buscaba confrontar las marcas de la lógica de la dominación en el discurso dominante y la lógica de la resistencia en el discurso popular. Para este último, el objetivo de su acción no estaba en imponer una fuerza incontrarrestable que iterara las mismas prácticas totalizantes del sistema cultural que se deseaba desterritorializar. Contrario al principio de la autoridad en cualesquiera de sus formas, su estrategia de resistencia no concebía una institucionalidad para ejercitar una acción voluntariosa, sino para controlar las fuentes de poder desde donde se generaba el sistema de creencias y representaciones, legitimadoras de un determinado orden. Por cierto que la consumación exitosa de un plan de conquista como el que consideraba la estrategia libertaria no estaba exenta de elevados costos, partiendo por la cancelación de los canales existentes encargados de producir y difundir la cultura oficial. A pesar de que el escenario de lucha mostraba una manifiesta asimetría a favor de los agentes del sistema vigente, el anarquismo, 
desde su irrupción en el país, mostró la voluntad de afrontar cohesionadamente la oposición de los adversarios. Sus movimientos estratégicos no sólo convocaron a sus partidarios, sino que trabajaron, además, con la idea de ampliar su esfera de influencia hacia los sectores mesocráticos más sensibles a la problemática social que afectaba a ingentes sectores de la población.

Difícil resultaba en este ámbito de la cultura confrontacional sobreponerse a la imposición que el discurso del poder hacía de la interpretación del mundo, puesto que funcionaba tras el aparataje oficial una decisión gubernamental de intervenir en todas las etapas del proceso de construcción de una imagen de realidad funcional a los intereses y a la subsistencia de un régimen elitista. Su reacción ante la disidencia era la de desestimar cualquiera otra visión que entrañara una imagen distinta a la sacralizada. Una de las formas alternativas que la escritura ácrata proponía simbólicamente en respuesta a la sancionada por las minorías dirigentes remitía a otras realidades alternativas, colocadas más allá de la realidad cotidiana, porque "más allá significa distancia espacial, marca un avance, promete el futuro" (Bhabha op. cit. 19). El referente de este lugar, que Heidegger definía como un evento en que "algo comienza su presentarse", estaba en el ámbito de la moral, a partir del cual era posible contraponer la lectura libertaria con la lectura ilustrada atravesada de un sentido particular de afirmación de lo moderno. La interpretación de este mundo auroral se basaba en un sistema de creencias y valores que tenía como centro de la atención la naturaleza humana y su destino, matizando la mirada con la detección de las fortalezas de lo humano, pero también sus debilidades. En el caso de las fortalezas, la posibilidad de hacer realidad lo que para los anarquistas representaba el cenit de sus aspiraciones: la instauración de "el mejor de los mundos posibles" resultaba una labor cada vez más factible, dado que "Sin la idea de posibles, la voluntad libertaria de una transformación radical del mundo actual resulta impensable" (Colson 2003: 193). Respecto de las debilidades, a diferencia del discurso consensuado de las minorías privilegiadas, la contemplación de la realidad de los ácratas no disimulaba las contradicciones e incoherencias en que solían incurrir muchos de los exponentes de los sectores postergados, cuando no esa evidencia se hacía extensiva a toda la sociedad preterida. Llevados por el espíritu regenerador que envolvía todas las causas que emprendían, la respuesta orgánica a aquello iba por el lado de la implementación de todo un operativo teórico y pedagógico, funcional a los propósitos de regeneración del individuo. Superar los vicios que los consumían y desarrollar en ellos una conciencia crítica que los llevara a pensar por sí mismos, ajenos a cualquiera tutela intelectual y moral ideológicamente partidista o confesional, era el compromiso que asumían, teniendo como única divisa la instauración de un mundo mejor.

La misión autoimpuesta del anarquismo de desenmascarar el discurso oligárquico, revelando los espacios donde subyace la violencia simbólica, la lleva a enfrentar los valores codificados del poder. El corolario de este enfrentamiento será la relativización de la presunta organicidad de la realidad postulada por la jerarquía gobernante. La herramienta que utiliza para mostrar las contradicciones del adversario será la construcción de un contradiscurso que mostrará, primero, sus mecanismos de resistencia a la distorsión de la cultura afirmativa y, segundo, luchará por establecer sus propias instancias de creación de sus productos simbólicos y sus propios espacios de mediación doctrinaria. Las marcas de la resistencia en el discurso libertario se expresan de manera directa, sin contenciones ni veladuras que enmascaren la realidad. 
Lo que se buscaba, en definitiva, era revelar los territorios que el discurso oficial ocultaba o negaba, no tanto para enrostrar la violencia implícita que se ocultaba tras este silenciamiento, sino para redescubrir los espacios que potencialmente podrían derivar hacia "el mejor de los mundos posibles". La resistencia estaba precisamente en la capacidad del sujeto de ir más allá de los límites establecidos por una sociedad disciplinaria y castigadora, buscando en los intersticios del mundo las napas residuales que contribuyeran a una mejor comprensión del mundo por hacer. No se trataba de edificar una nueva realidad a partir de las ruinas de la precedente, sino superponerla, de manera de crear las condiciones que hicieran posible la interacción de lo nuevo con lo antiguo, pero bajo un código moral y cultural diferente. La fórmula para salir del callejón creado por la cultura patriarcal la ve el discurso libertario llevando adelante un proceso colectivo ético de interculturalidad en el que la composición binaria de la sociedad fuera zanjada por la disposición tanto de los estados nacionales como de sus múltiples y variadas manifestaciones a fusionar aquellos contenidos de la tradición y de la historia que resultaran comunes para los modelos originalmente discretos ( $\mathrm{Cf}$. García C. 2005:21), sin que ello importara la anulación de la pluralidad y la diversidad. "La interculturalidad significa interacción entre culturas, interpenetración, pero también la mantención, dentro de un marco intercultural más amplio, de la pluralidad y diversidad cultural, a través de la escuela, de las leyes, de las lenguas, de los símbolos" (Garretón 2003:64). Este paso de una dimensión a otra se haría a través de la capacidad del sujeto para crear un espacio cultural convergente que permitiera compartir ideas, valores y principios dentro de un acuerdo social donde imperaría la racionalidad comunicativa. Se instalaba el derecho a significar desde la periferia, y el privilegio no dependía del peso de la tradición, sino del poder de la tradición para reinscribirse mediante las condiciones de contingencia y contrariedad de los que están en la minoría (Cf. Bhabha op. cit., 19).

\section{CREACIÓN, DIFUSIÓN Y VALORACIÓN DE LOS BIENES SIMBÓLICOS DE LA CULTURA LIBERTARIA}

De la misma manera como el sistema de ideas dominante mostraba sus primeras fisuras en su estructura institucional, la cultura oficial reveló su erosión en las imágenes y representaciones fundamentales de unidad y armonía del modelo de sociedad de la época. Para Bernardo Subercaseaux, las causas de las alteraciones del marco cultural tradicional, desde las postrimerías del siglo XIX, obedecían a razones histórico-sociales como la ampliación y diversificación del universo simbólico y al incremento paulatino de centros alternativos de creación y divulgación (Subercaseaux 1997: 175, T. II). Con el advenimiento de los primeros lustros del siglo siguiente, se acentúa el fenómeno de la diversidad cultural al emerger grupos sociales con capacidad organizativa para defender sus derechos y sus espacios específicos ante la regulación de los significados impuestos por el Estado y administrados por las mediatizaciones hegemónicas del monoculturalismo elitista. Se da paso a una lucha abierta por el control de los significados. El objetivo principal de estos grupos contestatarios apunta al Estado y al modelo capitalista de desarrollo a los que culpan de ser los responsables de instaurar mitos de integración social que, en la práctica, significaban más segregación y mayor incapacidad para resolver las necesidades básicas y aceptar pensamientos disidentes. 
Se quiere revisar la comprensión ritualizada de la realidad, oponiendo una perspectiva diferente que incluya la diversidad en los actos de vida.

Los primeros intentos del anarquismo por crear las condiciones que posibilitaran el desplazamiento del control de los sistemas simbólicos en manos de los sectores oligarcas de la sociedad, fue la creación de numerosas células ácratas, cuya meta era la de enseñar "la verdad" libertaria y, paralelamente, generar publicaciones que se encargaran de difundir la palabra del movimiento y ampliar su zona de influencia. Estas células, centros, sociedades o ateneos se constituían de manera espontánea en todos los lugares en que existiese un número de partidarios dispuestos a establecer un contrato voluntario que les permitiese operar colectivamente en la construcción, asimilación y transmisión de un saber alternativo que replanteara los términos con los que se entendía y valoraba la realidad. Con estas instancias de aprendizaje y reflexión se pretendía cubrir campos educativos que iban desde alfabetizar a obreros y personas que lo necesitaren, independientemente de su cercanía o no a la orgánica anarquista, pasando por la formación de líderes que cumplieran con su labor de conducción en el campo gremial, hasta el diseño de estrategias para los movimientos huelguísticos. El carácter voluntario de estos grupos hacía que sus participantes asumieran libremente los contenidos doctrinarios que mejor contribuían a comprender el entorno y sus propias experiencias de vida. El origen planetario de estas formas básicas y acotadas de organización estaba en los clubes, sociedades populares y círculos fraternales nacidos de la Revolución Francesa para cumplir, dentro de la sociedad burguesa, con objetivos de carácter social, ideológico y cultural. Este impulso societario que, en cierta forma, entraba a competir con las políticas institucionales del Estado burgués vigente, se profundizaba en la misma medida que el avance del desarrollo capitalista ahondaba las injusticias sociales y olvidaba lo humano. Con el desarrollo del capitalismo industrial, "ese nuevo e imprevisto sistema de injusticia" - dice Chomsky- corresponde al socialismo libertario preservar y difundir "el mensaje humanista radical del Iluminismo" (2003:19).

Reeditando el legado iluminista y utópico, el socialismo libertario recogió el mandato doctrinario de formar a los trabajadores por medio de una educación que incentivara espiritualmente su liberación y su crecimiento personal. Había que terminar con la hegemonía exhibida en este terreno por las élites que predicaban una enseñanza que, como sistema, profundizaba las desigualdades. La meta cultural de la educación libertaria era la de fomentar un cambio en las maneras canónicas de pensar, actuar y organizarse. El flagelo de la miseria era el más vivo ejemplo de cómo, por la ignorancia, el hombre vegetaba en las condiciones más indignas y, por la ignorancia, terminaba siendo presa fácil de la voracidad capitalista, prolongando la explotación y la injusticia. Este baldón social sólo podía ser erradicado a través de un proyecto educativo alternativo que el movimiento estaba dispuesto a encauzar haciendo uso de la extensa red de medios de formación e información ${ }^{1}$. Así como los círculos, sociedades, ateneos y agrupaciones ácratas se ocupaban de formar y preparar a los futuros activistas y adherentes de la causa, la difusión de los contenidos derivados del trabajo al interior de estos talleres requería de un espacio razonable para marcar su presencia en el mundo exterior, en especial en el mundo de los trabajadores. Este

\footnotetext{
${ }^{1}$ Sobre las diferentes formas grupales de concientización social del anarquismo, véase el Capítulo II de mi libro Antología crítica de la dramaturgia anarquista en Chile, pp. 47-107.
} 
objetivo difusor dio forma a una de las tareas centrales del proceso de validación del pensamiento ácrata en la sociedad progresista como lo fue la creación de una prensa libertaria. Esta tarea indicaba que, tan pronto la palabra ácrata comenzara a irradiarse más allá de los intramuros societarios, se daba comienzo a un programa a favor de la creación y divulgación de numerosas publicaciones, las que se incrementaban en la misma medida que los conflictos sociales se agudizaban. Su despliegue masivo a lo largo del territorio permitía contrarrestar la penetración privilegiada que alcanzaban las empresas y medios periodísticos de los sectores capitalistas, más preocupados de defender sus territorios simbólicos de las incursiones mediales del progresismo humanitarista. Había un par de razones que justificaba la irrupción de la prensa libertaria. En primer lugar, el diario o la hoja periodística cumplían de manera más rápida y efectiva con la misión de difundir el ideario que lo que podía lograr el trabajo de taller. Si bien es cierto que los circuitos de difusión anarquistas no podían competir en número ni cobertura con la prensa establecida, al menos, con lo que se contaba, se podía cumplir a cabalidad con el propósito de transmitir el repertorio de preferencias temáticas y valóricas de una cultura popular ignorada o amordazada por el poder dominante. En segundo lugar, la palabra escrita cumplía con la necesidad de entregar el mensaje en forma de manual o catecismo de instrucción, con lo que se aseguraba la comprensión e internalización de los contenidos propuestos. En la mira estaba puesta no sólo la orientación a perfeccionar el hacer del sujeto, sino el ser y el deber ser; se pretendía definir las situaciones y el significado del mundo, ligado a la experiencia vital del individuo. El objetivo era, como lo sostiene Bravo Elizondo, "estimular al obrero, sacarlo de su inercia, organizarlo" (1986:47), otorgándole los instrumentos que hiciesen del activista libertario un sujeto funcional desde el punto de vista personal y de sus relaciones sociales. A diferencia de las publicaciones comerciales o ideológicas restantes, estos diarios traían formatos de impresión que no daban cuenta obligadamente de las noticias de la coyuntura ni tampoco secciones que recogieran información de otros campos de la actividad nacional que no fueran las que se relacionaban con las preocupaciones libertarias. Los espacios de los impresos se destinaban a reproducir ideas, pensamientos y pronunciamientos de los patriarcas de la agrupación internacional. También se ponía especial énfasis en consignar las actividades y programaciones de los distintos centros anarquistas. Cabían en estas columnas las informaciones y los comentarios sobre las actividades doctrinarias, culturales y artísticas de los núcleos locales y regionales. Sin embargo, todo el peso de la diagramación descansaba en los dos grandes temas que importaban a la orgánica ácrata: los relacionados con la doctrina y los de denuncia. Ello se correspondía con el compromiso comunicacional de acercar los signos, símbolos y posiciones que el discurso anarquista producía con la intención de que los destinatarios del mensaje pudieran elaborar sus propias respuestas en relación con los desafíos que le imponía el decurso de sus vidas dentro de un orden cuyos espacios no estaban disponibles para estos sectores disidentes de la línea oficial. De esta forma, la estrategia consistía en copar aquéllos que el resto de la prensa progresista o de izquierda no llenaba, ya por tácito acuerdo con los editores, ya porque el círculo de lectores respondía a preferencias ajenas a los intereses laborales.

Fuere uno u otro el caso, la reacción de la prensa anarquista se centraba en desarrollar un tipo de recepción crítica respecto de la información que las publicaciones tradicionales traían en sus páginas, responsables éstas del perfil pasivo de los 
lectores que la prensa societaria rechazaba de plano. En este espíritu de crear en sus destinatarios una conciencia recusadora, la actitud de muchos adherentes al ideario aplicaban su espíritu crítico al propio contenido de las publicaciones de la causa. Temas altamente sensibles, como la práctica del amor libre, entendida como la unión de la pareja al margen del matrimonio, o el de la educación, generaban al interior del círculo de lectores ácratas encendidas polémicas, alentadas por la línea editorial del diario que quería con ello movilizar las conciencias un tanto adormiladas de sus adeptos. Este procedimiento alcanzaba significativas respuestas de este calibre especialmente dentro de los centros libertarios, donde se tenía la costumbre de leer en voz alta el material impreso para los iletrados que, en número importante, conformaban estas entidades comunitarias.

Estas estrategias aseguraban la reafirmación de parte del ideario del programa de concientización popular a que estaba comprometido, sin pausa ni concesiones, puesto que la lucha era una guerra declarada contra los espacios contaminados con la prédica oficial. Había que neutralizar sus mensajes y definiciones valóricas y sociales que, revestidas de una retórica igualitarista, ejercían presión sobre el lector ingenuo. El recurso por el cual se buscaba la compensación a estos desequilibrios comunicacionales era el de emplear un tipo de lenguaje más de acuerdo con los registros populares, como frases o expresiones que gatillaran el sentimiento exacerbado de conmiseración o animadversión. El propio estilo de los redactores buscaba los recursos del lenguaje que despertaran conductas intensificadas, generando un "pathos" que actuara sobre la vida afectiva y pulsional de los destinatarios. A pesar de que estas claves discursivas de inspiración melodramática eran desestimadas por la prensa adversaria por su carácter popular, con "mínima posibilidad de verdadera cultura" y por ser consideradas "únicamente como espacio de reflejos culturales, de reacciones, de vulgarización, abaratamiento y degradación" (Barbero 2002: 137), su utilización era consciente, porque a través de sus efectos emocionales se conseguía un gran objetivo: dar curso a la espontaneidad del hombre corriente, sometido por siglos a una contención espiritual, en nombre del bien común. Para el anarquismo, la vida cultural de los pueblos no era más que el producto de un discurso heredado que en su enunciación traía las marcas de la represión psicológica y de la conculcación de las libertades básicas del hombre. Con el estilo "melodramático", se buscaba despertar los sentimientos y pasiones mediante la intensificación de los cuadros de vida desplegados en la página diaria, en virtud de lo cual lo que permanecía latente en el fuero interno explotaba con fuerza hacia el exterior, determinando patrones de conducta diferentes en el lector, lo que significaba un quiebre con la cultura represiva heredada. Como lo afirma MartínBarbero, "los anarquistas fueron la fuerza de izquierda que había entendido el sentido a la vez cómplice y subversivo de la cultura popular sabiendo apoyarse en sus saberes y creencias para generar conciencia revolucionaria (op. cit., 22).

La particularidad que colaboraba de manera decisiva a este sesgo melodramático del discurso periodístico era la manera polarizada con que el ideario ácrata interpretaba el mundo. Si visión bipartita reconocía los términos en que se debatía la existencia del hombre moderno: el que detentaba el poder derivado del capitalismo liberal y el que sobrevivía bajo "el peso de la noche", sin esperanza alguna de encontrar su libertad e independencia. La escritura cargaba sus tintas, ya para denigrar, ya para exaltar. En la primera condición, el panorama social era visto como el polo de la explotación, la discriminación y la corrupción, realidad que la prensa anarquista anatematizaba 
y denunciaba para debilitar su poder hegemónico y actuar sobre él, desplazándolo cultural e ideológicamente del centro del poder. El polo contrario estaba constituido por la gran mayoría de los sometidos, que sobrellevaban una lucha heroica contra el modelo de desarrollo capitalista, con costos a veces muy elevados en vidas humanas, inmolación que la prensa militante exaltaba, presentándola ante la opinión pública como auténticos mártires de la causa libertaria. La hoja periodística estaba detrás de esta imagen, y su discurso tenía por misión la emergencia de las columnas revolucionarias que impondrían su propia cultura y su propio espacio de pertenencia, con los principios, valores y cosmovisión de la idea emancipadora. Desde esta perspectiva, la prensa libertaria era el dispositivo por medio del cual haría posible que la Nación lograra imponer su cultura alternativa e insurgente. Mientras ello no fuera realidad, se debían afinar los mecanismos de resistencia al poder hegemónico, profundizando la lucha contra el capitalismo despiadado.

\section{LA INTERVENCIÓN POÉTICA DE LA REALIDAD Y LA CREACIÓN DE UN MUNDO MEJOR}

El cometido principal del movimiento libertario de comienzos del siglo XX fue el de afianzarse en el repertorio de ideologías circulantes en Chile. Todo su plan de acción apuntaba en esa dirección, desde crear sus propios centros de producción cultural e implementar un circuito de divulgación de sus principios hasta influir en los procesos internos y externos de validación de su discurso. Uno de los componentes de este proceso era la escritura dramática, la que, junto a la representación teatral, contribuía a abrir nuevos niveles de realidad al destinatario y a conocer nuevos significados que le hicieran comprender su situación en el mundo, sus posibilidades de mejoramiento y rechazar, asimismo, las imágenes afirmativas transmitidas por el discurso oficial. Para los articuladores culturales del anarquismo, el texto dramático era un excelente complemento para las tareas de formación al funcionar como reforzativo de una acción de enseñanza que se basaba en la palabra escrita, lenguaje privilegiado para fijar los conceptos, principios, valores y creencias propios. La ficción se la estimaba en cuanto era capaz de seducir y suscitar compromisos que se ligaran con la acción revolucionaria y se convirtiera en apoyo a la labor educativa. Los signos, imágenes y representaciones de la textualidad dramática se ponían al servicio de la causa con el fin de proporcionar las herramientas intelectuales y procedimentales que contribuyeran al cambio revolucionario del hombre y su circunstancia.

La definición de la literatura en términos de ser un mecanismo verbal destinado a formar una conciencia revolucionaria significó para las convenciones dramatúrgicas, en particular, y literarias, en general, una desviación de la norma que predicaba una imagen de mundo conteste con la cultura afirmativa del discurso literario de la época y, para su propia escritura, un compromiso militante con la idea de crear un mundo diferente, para lo cual había que escribir distinto de los demás, y pensar la realidad como posibilidad diferente.

En un momento de fijación de las bases de la literatura contemporánea en Chile, pretender mantenerse al margen de los cánones regulatorios de la creación literaria significaba ir contra la institucionalidad estética dominante y sentar un precedente peligroso en cuanto a validar discursos que ponían en cuestión los principios, valores y visión de mundo del modelo de sociedad existente. La primera señal desafiante será 
la de establecer como punto de hablada del creador la realidad popular, desde la cual se discurría y se relataba desde la esencia misma de lo marginal. No se trataba tan sólo del acto retórico de hablar sobre "el pueblo abandonado" como acostumbraba a hacerlo el poeta naturalista, sino que el alcance del texto libertario iba más allá de lo factual para sumergirse en la realidad popular, vivenciando su palpitar y metaforizando sus demandas y expectativas. La alternativa que proponía el humanitarismo libertario era la de reescribir lo real desde una posición comprometida. El discurso dramático operaría como intermediario entre el mundo representado y los cambios que debían producirse al interior de un sistema que funcionaba en torno a su propia concepción elitista de la realidad. El contenido de las historias comunicaría el repertorio de símbolos que, en la práctica societaria diaria, había probado ser el acicate poderoso para encender las capacidades potenciales de crecimiento, de entendimiento y de solidaridad que cada individuo almacenaba en su espíritu. Gracias al conjuro de la palabra poética, el destinatario despertaría de su cerrazón secular, producto del tutelaje ético-moral ejercido por el eliticentrismo cultural. Esta mirada solidaria sólo provendría de la sensibilidad artística capaz de traducir en imágenes lo que vivencialmente había experimentado en ese mundo olvidado. El hablar de él tenía un sentido ontológico más que sociológico, y ese alcance era el que la dramaturgia anarquista pretendía rescatar.

El compromiso militante con el que se presenta la creación dramática libertaria buscaba el espacio cultural que hiciese posible derrocar lo existente para poner en su lugar una dimensión moral nueva. Profundizaba su compromiso de proponer horizontes que fueran paliativos a la marginalidad y la represión. Tanto la arquitectura dramática del texto como sus propuestas valóricas e ideológicas están pensadas para romper con la imagen unitaria, armónica e inconmovible que el discurso oficial ofrecía del orden social dominante. Las innovaciones en la estructura dramática de la composición y el punto de vista con el cual se abordaba el sistema de preferencias sancionado por la institucionalidad realista y burguesa harían del programa dramatúrgico anarquista la herramienta de ruptura, de espíritu vanguardista y contestatario.

\section{TRADICIÓN ESTÉTICA Y RUPTURA EN EL DISCURSO DRAMÁTICO LIBERTARIO}

Situar la obra dramática anarquista en un contexto estético supone reconocer la existencia de una práctica de reflexión acerca de lo que se debe entender por arte y las características que lo acreditan como tal. Suponer que la actividad literaria de los creadores ácratas iba a regirse por reglas o normas inventivas, significaba ir a contrapelo de lo que los propios anarquistas declaraban como acto de fe: su desapego a cualquier forma exterior de dominación, que, en este caso, representaba el acatamiento a criterios normativos de una poética. Una lectura exploratoria de los textos dramáticos divulgados entre fines del siglo XIX y la tercera década del siglo pasado revela la instauración en todos ellos de un espacio alternativo al que se reconoce históricamente como válido ${ }^{2}$. Ello no quiere decir, sin embargo, que se da la espalda a la realidad concreta; más bien, se trata de yuxtaponer a lo existente un nuevo orden,

2 Las obras que nos sirven de objeto de referencia son las siguientes: Suprema Lex (1895) de Rufino Rosas; Flores Rojas y Los Vampiros (1929) de Nicolás Aguirre Bretón; Un hombre (1914) y El Sábado (1923) de Adolfo Urzúa Rozas; Los grilletes (1927) de Alfred Aaron y Los Cuervos (1937) de Armando Triviño. 
cuyas características se entroncan con lo que la filosofía leinitzeana postula como "el mejor de los mundos posibles", territorio que, para los anarquistas, subyace en forma residual al mundo exterior (Colson 2003: 97).

Ir más allá, donde este mundo "comienza su presentarse”, envolvía como acto la más genuina de las verdades libertarias en el campo del arte: la libertad de crear. Desde Owen, Fourier y Proudhon, la libertad era vista como el poder absoluto que no se hipotecaba bajo ningún otro valor. Su ejercicio era soberano, al margen de cualquiera intermediación. Es por ello que, cuando el dramaturgo crea el texto, lo hace siguiendo su propio impulso creador. Su misión no consiste en seguir las teorías estéticas al uso, ni menos la preceptiva poética que se desprende de ellas, sino en dar expresión a las fuerzas potenciales que lo constituyen como sujeto creador. Para el ideario, todo trabajo era un acto creador, porque quien lo ejercía liberaba desde su interior los impulsos creadores capaces de cambiar lo establecido, acto emancipador que, inclusive, se colocaba por encima de la obra creada, reflejando la absoluta autonomía del objeto creado en relación con los dictados poéticos validados por el discurso oficial. El trabajador era poeta cuando su actividad la orientaba a colocar un elemento nuevo a la realidad existente: había arte cuando se añadía la novedad al universo ya creado ${ }^{3}$. Pese a la cercanía del movimiento con otros ejercicios literarios de compromiso social, como el naturalismo, el arte libertario dejará señalada su distancia al considerarlo un arte burgués que no luchaba por el cambio, en los términos de transfiguración poética que predicaban los anarquistas, sino por aquello que reafirmaba lo existente y "donde la anatomía de la sociedad aparece en toda su crudeza, disociada de los ideales éticos y sociales" (Cappelletti 1985: 66).

El verdadero compromiso del artista debía estar, según Kropotkin, "en medio de este mar de angustia cuya marea crece en torno a ti, en medio de esa gente que muere de hambre, de esos cuerpos amontonados en las minas y esos cadáveres mutilados yaciendo a montones en las barricadas /.../ tú no puedes permanecer neutral; vendrás y tomarás el partido de los oprimidos, porque sabes que lo bello y lo sublime-como tú mismo- está del lado de aquéllos que luchan por la luz, por la humanidad, por la justicia" (en Pellettieri op . cit. 65). El arte comienza, dice Tolstoi, cuando el hombre creador es capaz de hacer sentir a otro lo que a él le produjo lo contemplado, sea un sentimiento de alegría, de tristeza o abatimiento.

Aunque su concepto de arte auténtico se formula como signo opuesto al arte dominado por los intereses individuales del burgués y la inclinación fagocitaria del Estado nacional, la dramaturgia ácrata no estaba al margen de las milenarias especulaciones acerca del modo como se consumaba el arte, cuáles eran sus medios de expresión y sobre qué construía su representación. Daba paso a una reflexión que no podía dejar de hacer, tratándose de una construcción artística, cuya última meta era revelar una intencionalidad y efecto estéticos que plasmasen la idea libertaria de un mundo mejor. Dado que el programa literario del anarquismo se trazaba como actividad central la de crear un mundo adicionado con niveles de realidad inéditos, suficientes para instaurar un mundo nuevo, la "mimesis" libertaria rompería con el

\footnotetext{
${ }^{3}$ Esta definición explica el que la literatura libertaria pudiera ser practicada por obreros, sin necesidad de acreditar una destreza previa para ello. De hecho, varios de los escritos divulgados por las publicaciones afines en Chile correspondieron a contribuciones de los socios de las mancomunales, centros culturales, filarmónicas y otras formas organizacionales anarquistas.
} 
arte de la reproducción tradicional para convertirlo en un acto estético de la transfiguración, proyectado hacia el interior de la realidad misma. Más que una imitación, el arte libertario es la revelación de un mundo otro que, al ser plasmado estéticamente, sale de su condición residual para emerger como la auténtica realidad. Lo que los textos comunican simboliza el espacio deseado, donde las exclusiones, el desarraigo y la represión dan paso a la inclusión social, a la diversidad cultural y a la solidaridad entre los hombres.

$\mathrm{El}$ arte libertario marca su sello rupturista e innovador apelando a esa fuerza creadora que hay en todo individuo y que lo lleva a participar en ese acto creativo liberador que lo impulsa a ir más allá de lo establecido, adicionando una nueva realidad, estructuralmente más igualitaria y moralmente más plena. Como lo recuerda Henri Gouhier, basándose en la definición de Etienne Wilson, en 1906: "La obra de arte es una realidad nueva que el artista añade al universo" (1961: 31). Todo hombre tiene un "poder de determinación" que potencialmente puede ser activado, según sean las causas que lo desencadenan. Más allá de la teoría del reflejo, el dramaturgo crea por obra de este poder, no siguiendo los lineamientos del referente externo, impositivo y jerárquico, sino recogiendo y seleccionando del trasfondo de la realidad aquellas partes con las que el artista puede recomponer y reinstalar una nueva realidad (Naugrette 2004: 14). Esta apropiación dinámica y funcional permite al drama libertario intervenir la realidad, con los resultados estéticos que ya Aristóteles en su Poética reconocía, en cuanto a la voluntad de instaurar un mundo "tal como debiera ser": "De lo que hemos dicho, surge claramente que el papel del poeta es decir no lo que verdaderamente ha tenido lugar, sino lo que podría tener lugar en el orden de lo verosímil o de lo necesario. Porque la diferencia entre el cronista y el poeta no reside en que uno se expresa en versos y el otro en prosa /.../, sino que la diferencia es que uno dice lo que ha tenido lugar y el otro, lo que podría tener lugar" (1990: 11).

La desestructuración de las realidad que se propone el discurso dramático emancipador parte del supuesto de que el universo por recrear ya existió, por lo que el adicionamiento inventivo considera ese mundo olvidado, posible, porque ha sucedido anteriormente, y lo posible emerge cuando hay la sensación de que algo distinto puede ocurrir en la vida corriente de una sociedad habituada a lo previsible. Este predicamento convierte al discurso dramático anarquista en una versión actualizada de un espacio anterior, enriquecido por el decurso de los siglos y susceptible de ser abordado, por medio de la intervención poética, y convirtiéndolo en algo nuevo. Así como el revivir historias reprimidas impulsa el acto de crear a ámbitos liberados de la violencia simbólica ejercida por el discurso dominante, la revisión creadora del presente será capaz de llegar a esas capas residuales donde existe ese mundo otro, liberado de la lógica del binarismo y alentado por el recurso cultural de la "apropiación"4. La naturaleza productiva del pensamiento inventivo autoriza al anarquismo a rechazar el calificativo de utópico con que sus adversarios pretenden descalificarlo. Lo constructivo, según Guèrin, consiste en trabajar la sociedad futura no como una imagen que no tiene lugar (u-topia), sino como una sociedad que es producto del trabajo subterráneo del pasado 2003: 69).

\footnotetext{
${ }^{4}$ Para Martín-Barbero, op. cit., apropiación significa rediseñar los modelos culturales otros para que quepa la heterogénea y múltiple realidad, instalando "un lugar diferente a aquél en que se escribieron".
} 
Las resonancias que produce la imagen de una comunidad primitiva que, en el orden de los valores y el sentido de la justicia y la solidaridad mantienen tantas semejanzas con el pensamiento libertario, se harán presentes cada vez que se quiera concebir poéticamente un mundo alternativo al existente. Lo significativo de esta operación de recomposición de los planos materiales está en que la voluntad creadora del dramaturgo se carga de una idea fuerza capaz de cambiar radicalmente tanto el sentido como el curso de la historia. Esta vehemencia en el pensar y en el hacer es lo que Proudhon llama revolución. El alcance de la idea fuerza se explica porque la propuesta de imagen de mundo no es una imagen acabada; más bien, su realización pende de la voluntad de determinación del artista de querer plasmar su idea del mejor de los mundos posibles. Como lo sostiene Colson, "Sin la idea de posibles, la voluntad libertaria de una transformación radical del mundo actual resulta impensable" (Colson 2003: 193).

El cruce de tradición e innovación que se produce en la concepción del programa dramático anarquista permite entender el sentido último de la creación literaria. Por una parte, afirma la condición de texto artístico. Por la otra, su marca distintiva radica en el establecimiento de una red de relaciones que afecta directamente a los tres planos de realidad comprometidos en la propuesta dramática: el mundo del pasado remoto, cuyos contenidos valóricos afirman la dignidad del hombre; el mundo del presente histórico que ha perdido todo sustento moral, enajenando la condición humana, y el mundo del futuro, "el mejor de los mundos posibles", cuyo sentido y proyección quedan en manos del poder de sugestión del lenguaje de su creador y del conjunto de saberes, creencias y aspiraciones del lector.

\section{LA INTENCIONALIDAD Y EL EFECTO ESTÉTICOS DE LA DRAMATURGIA ANARQUISTA CHILENA}

Toda estética persigue un fin que no puede ser otro que el que le dicta su forma genérica. En el discurso dramático, el tipo de representación supone una voluntad humana movida por aquello que debe ser, para lo cual los actos que resultan de esa voluntad se "encaminan a derrocar los existente" (Staiger 1966: 161). Este actuar con proyección es lo que genera en el discurso dramático el atributo de la tensión, puesto que todo tiende hacia el punto donde se quiere llegar. Estos rasgos genéricos son los que ayudan al discurso anarquista a llevar adelante su concepción particular del mundo, de acuerdo con los principios y creencias de sus postulados doctrinarios. El texto libertario acota el funcionamiento de la realidad representada a partir de la caracterización de las fuerzas que intervienen en el proceso de construcción de un nuevo orden. Tomando lo dramático como eje en torno del cual se aglutinarán los diferentes sentidos, su dramaturgia se abrirá a los tres espacios que constituyen los fundamentos de la nueva realidad que se pretende alcanzar. El compromiso de derrocar lo existente está expuesto por el objeto mismo sobre el cual se interviene, y que es la realidad plasmada en el texto. Conforme los principios del arte definidos por el anarquismo, la imagen de realidad propuesta para su revisión y transfiguración no está sacada de los libros, sino que tiene que tomarse de la vida misma (Kropotkin). Esto se hace patente en la práctica creadora debido al convencimiento de que hay siempre en el conjunto de la realidad una parte muy vasta de donde emergen las potencialidades 
forjadoras de un universo oculto, pero tan pujante como la vida misma. A estas capas sedimentales corresponden los otros dos planos a que alude la escritura dramática, y que funcionan como entes innominados presionando la superficie del mundo representado con el propósito de intervenirlo poéticamente. Este juego de lo explícito y lo implícito sirve para elaborar el proyecto que guiará los pensamientos y los actos de las figuras encargadas de situarse "de antemano" ante lo que ha de venir. Mientras el contenido del mundo práctico aparece definido con toda la carga de contradicciones y falencias estructurales, los dos restantes sólo intervienen por ausencia activa, contrastando sus términos con la realidad actual, en un caso, y proyectando una nueva imagen de mundo más allá de la unidad de sentido con que el discurso oficial reviste su existencia, en el otro caso. El primero de estos espacios adquiere la tonalidad de una afirmación de los valores esenciales de lo humano, la que aparece contradicha por el presente de la representación. El porvenir, en cambio, aparece en el texto como la resultante de la recomposición de la realidad desestructurada, enriquecida por el aporte de las fuerzas interiores contenidas en las dos esferas restantes. Así como el mundo paradigmático surge en la obra como necesario, puesto que ha sido y, por lo mismo, es posible que vuelva a ser, lo que será está todavía en potencia, faltando para su concreción las causas que justifiquen su necesidad. De ahí, entonces, que estos mundos queden en el ámbito de las expectativas, lo cual impide, en consecuencia, representarlos. Es una intencionalidad estética que se funda en la participación activa del lector virtual quien, por esta misma razón, será el sujeto del efecto de la obra dramática.

Mientras mayor es la profundización de las asimetrías que muestra la composición de este espacio dominador, más potente resulta la percepción de los espacios ausentes, los que se mantienen vigentes a través de los variados indicios que entregan los discursos de las figuras que encabezan los actos emancipadores. La fuerza que nace de las palabras de los personajes apunta a un "para" y plantea la pregunta de "un en virtud de qué" (Staiger op. cit., 176), con lo cual se hace evidente la intencionalidad del texto por establecer un nuevo nivel de comprensión de la realidad histórica. Para el dramaturgo, el mundo nuevo es la resultante de la expresión de la fuerza interior que hay en cada sujeto que, al ser interpelada por medio del discurso dramático, es capaz de manifestarse constructivamente llenando de sustancia el espacio intuido. El despertar del sujeto deriva de la conminación a que es sometido por parte de un lenguaje intensificado que introduce pensamientos claves -libertad, justicia, verdad-que anticipan que algo puede producirse en reemplazo de lo existente, y que impulsan a asumir su tarea con pasión. Como lo afirma Emilio Staiger, este tipo de discurso se caracteriza por su fuerza destinada "a mover a los hombres". Esta proyección de la mirada del dramaturgo hacia territorios que sobrepasan las fronteras de lo presente, internándose en el futuro es consistente con las leyes que explican el funcionamiento dramático del mundo representado, puesto que este discurso "patético", según el teórico alemán, "presupone una resistencia, una abierta hostilidad o también una pereza, e intenta romperla con ahínco" (ya cit. 157).

El planteamiento estético de la escritura literaria anarquista apunta en la dirección de revelar lo que hay tras la caparazón de la realidad sensible. Ello supone que la intencionalidad es representar un mundo que deje al descubierto sus inconsistencias y contradicciones, pero que, a la vez, pueda ser intervenida para extraer de esas mismas contradicciones las claves que alienten la creación de un mundo "otro". Para Proudhon, la presencia de un mundo mejor ya tenía sus territorios penosamente construidos 
por la Humanidad tras seis mil años de sometimiento a la autoridad: "Por debajo del aparato gubernamental y de las instituciones políticas, la sociedad producía lenta y silenciosamente su propio organismo; se constituía un orden nuevo, expresión de su vitalidad y autonomía" en Guèrin op. cit., 9).

El tercer plano en juego en la conformación del mundo dramático anarquista se refiere a la existencia de un mundo evocado, "ese trabajo subterráneo del pasado", el cual serviría de base para proyectar un mundo otro. La imagen de este mundo mejor que el actual está tomada del modelo primitivo de sociedad. Esta mirada hacia lo primordial tiene la particularidad de buscar los fundamentos ideológicos que sustenten la creación de mundos posibles y, por lo mismo, alejada de todo tipo de utopismo cósmico. Los espacios representados con características emancipadoras recogen de aquel patrimonio vernacular los principios, ideas y creencias que permitan reeditar las experiencias sociales milenarias, conservadas en forma de experiencias residuales que, a lo largo de los siglos, se han ido renovando por el aporte hecho por cada generación y abriendo los espacios para mantener vivo el potencial de rectificación que hará realidad la sustitución de un orden por otro.

El que un dramaturgo libertario se proponga representar un espacio alternativo en respuesta al mundo empírico, tomando como paradigma el pasado residual, tiene que realizarlo sobre la base de la colaboración del lector; toda obra de arte -ha dicho Tolstoi- pone en relación al hombre a quien se dirige con el que la produjo.

Esta coparticipación en la cadena de formación de sentido del texto dramático es posible si se cumplen las condiciones suficientes para dar cabida al efecto estético buscado por parte del aparato productor. La coproducción del sentido que reconoce la estética anarquista parte del supuesto de que el "sentido artístico" existe tanto en el trabajador como en el capitalista, y que si varían las formas del sentimiento según la diferencia de cultura, su fondo siempre es el mismo (Kropotkin 1996: 94). Sin embargo, el compromiso de fundar una nueva realidad se plantea como una suerte de desafío para el lector, en el sentido de que lo que proporciona el texto no son más que indicios o señales que el receptor debe asimilar y articular en función de la imagen de mundo buscada. Esto es posible por el efecto desencadenante que produce el conjunto de sugestiones que trae el texto en su realización y los numerosos vacíos informacionales que lo atraviesan. La consecuencia inmediata de esta interacción autor-lector es la de diseñar una historia con final abierto que abre horizontes semánticos que prefiguran un mundo otro. Tal es así, que el mundo creado no es el que la obra le impone, sino el que resulta, también, de las vivencias, intereses, deseos, expectativas y saberes acumulados por el receptor a lo largo de su vida. Es esta actividad inventiva que la recepción pone en funcionamiento, apropiándose de la realidad siempre en movimiento, y cuya existencia se sostiene mediante la interacción de una infinidad de realidades posibles, de modo que cuando el lector construye su nuevo espacio está rescatando de ese repertorio el mejor, lo cual, sumado a los otros universos posibles, generará la auténtica realidad, es decir, aquella realidad que es la suma de las fuerzas colectivas interiores que, desde sus procesos creativos mismos, transforman en acto la imagen de un mundo mejor. Como lo afirma Jauss, "esta pluralidad de posibles interpretaciones constituye el carácter estético del texto" (en Mayoral 1987: 71).

Uno de los componentes fundamentales de los niveles compositivos de la dramaturgia ácrata, destinado a conseguir el afecto apelativo buscado, es la incorporación del melodrama. La función que cumple dentro del discurso dramático se asocia con 
la necesidad de repotenciar la capacidad creativa del sujeto receptor, adormilada por una cultura inhibitoria que ha ejercido sobre él una permanente acción tutelar, no sólo en el plano ético-moral, sino, además, en sus potencialidades inventivas. El melodrama es una forma artística, de larga data, que establece un modo de enfrentar la realidad por medio de la sublimación e hipertrofia de los sentidos, de los decires y de las situaciones como un expediente alternativo al condicionamiento estético de la cultura dominante. Su objetivo central es el de apelar a los registros sentimentales del lector con el fin de discriminar emocionalmente entre lo que corresponde a las buenas acciones y lo que las contraría. Con la definición del arte como un medio, el anarquismo busca poner al descubierto con estos recursos lo oculto de la realidad, es decir, aquello que se plantea binariamente como un orden libertario aplastado por la opresión exterior. Su despliegue como discurso devela las contradicciones e insuficiencias de un sistema incapaz de superar las desigualdades que oprimen a vastos sectores de la sociedad. La antítesis está planteada a través del recusamiento que la fórmula melodramática hace del principio de realidad, tan caro al imaginario burgués capitalista, que somete exclusivamente la significación e interpretación del mundo al poder de la razón, desechando la inagotable cantera de lo inefable, asociada al universo moral que promueve el surgimiento de un mundo latente ubicado más allá de las fronteras del lábil mundo histórico.

\section{CONCLUSIÓN}

La obra dramática anarquista se presenta en el complicado escenario social y cultural de comienzos del siglo XX en Chile como una de las formas de resistencia al discurso dominante de las minorías ilustradas. La primera acción encaminada a distanciarse de la dramaturgia oficial es la de incorporar una escritura que no reconozca los registros que estas minorías usan; desarrollar un pensamiento independiente que no apele a las fuentes a las que ellas apelan continuamente; instalar un espacio de expresión autosuficiente que trabaje con códigos literarios que no son los legitimados por la cultura oficial. En segundo término, su compromiso con el arte de la representación reconoce sólo aquel sistema capaz de dar forma a una realidad heterogénea, y no monocultural como las élites comunican sus imágenes ritualizadas. Por último, la dramaturgia libertaria rescata de la memoria las experiencias colectivas de un proyecto humanitarista de la Ilustración, olvidado en el presente de la escritura por una modernización que relegó al sujeto a la condición de enajenado.

\section{OBRAS CITADAS}

Aristóteles 1990. Poética. Caracas: Monte Avila Editores.

Bhabha, Homi. 2002. El lugar de la cultura. Buenos Aires: Manantial.

Bravo Elizondo, Pedro. 1986. Cultura y teatro obrero en Chile. Madrid: Michay.

Cappelletti, Angel. 1985. La ideología anarquista. Caracas: Alfadil Ediciones.

Colson, Daniel. 2001. Pequeño léxico filosófico del anarquismo. Buenos Aires: Nueva Visión.

Chomsky, Noam. "Prólogo" a Guèrin, Daniel. 2003. El anarquismo. Buenos Aires: Anarres 
García Canclini, Néstor. 2005. Culturas híbridas. Buenos Aires: Paidós.

Garretón, Manuel Antonio. 2003. El espacio cultural latinoamericano. Santiago: Fondo de Cultura Económica.

Gouhier, Henri. 1962. La obra teatral. Buenos Aires: EUDEBA.

Guèrin, Daniel. 2003. El anarquismo. Buenos Aires: Anarres.

Kropotkin, Pedro. 1996. La conquista del pan. Barcelona: Ediciones 29.

Martín-Barbero, Jesús. 2002. Oficio de cartógrafo. Santiago: Fondo de Cultura Económica.

Mayoral, Manuel Antonio. 1987. Estética de la recepción. Madrid: Arco/Libros.

Naugrette, Catherine. 2004. Estética del teatro. Buenos Aires: Ediciones del Sur.

Pereira Poza, Sergio. 2005. Antología crítica de la dramaturgia anarquista en Chile. Santiago: Editorial Universidad de Santiago/Consejo Nacional de la Cultura y las Artes.

Staiger, Emilio. 1966. Conceptos fundamentales de poética. Madrid: Rialp.

Subercaseaux, Bernardo. 1997. Historia de las ideas y de la cultura en Chile. Santiago: Editorial Universitaria.

Viñas, David. 2004. Anarquistas en América Latina. Buenos Aires: Paradiso Ediciones. 